\title{
Developing ESP Learners' Vocabulary Learning by Contextualization of the FonF Practice Model in CALL Context
}

\author{
Shiva Soltani \\ Islamic Azad University, International Kish Branch, Iran \\ shivasoltani06I@gmail.com \\ Ahmad Mohseni \\ Islamic Azad University, South Tehran Branch, Iran \\ amohseny1328@gmail.com
}

\begin{abstract}
The FonF practice model (focus on form) as a technology-oriented pedagogical model was contextualized to examine its efficacy on the second language (L2) learners' intentional and incidental vocabulary learning in computer-assisted language learning (CALL)as an attempt to integrate the emerging educational technologies into L2 learning. To this end, a sample of 55 medical ESP learners participated in a mixed methods research study that administered the FonF practice model-based treatment as the educational intervention among the experimental group. The findings confirmed the efficacy of the FonF practice model in developing incidental and intentional vocabulary learning among the participants who used technology-based tools at form, meaning, and communication levels. Theoretically, the main implication is the need to address individual differences in general and nonlinearity and dynamicity of motivation in particular. Pedagogically, L2 teachers are suggested to benefit from reported CALL tools to boost incidental and intentional vocabulary learning for ESP purposes.
\end{abstract}

Keywords: Dynamic Systems Theory; Technology-assisted language learning; nonlinear dynamic motivation; intentional and incidental vocabulary learning; computer-assisted language learning.

RECEIVED I JANUARY 202I/ACCEPTED 9 MARCH 202I @AUTHOR ALL RIGHTS RESERVED

\section{Introduction}

The use of the FonF (focus on form) practice model has demonstrated efficacious in providing students with appropriate motivational factors that cater to the nonlinearity and dynamicity at the individual level and utilizing the computer assisted language learning tools and affordances towards developing oral abilities (Bahari, 2019a). The FonF (center around structure) model of training presented by Bahari (2019b) was introduced and adopted based on the reported the adequacy of FonF-based guidance in its facilitative potentials for coincidental and predetermined second language (L2) learning (Bahari, 2019a; Fredricks et 
al., 2004; Pawlak, 2006). With regards to Nassaji (2016), the FonF was proposed as an ideal methodology for realizing which pointed toward blending the best highlights of second language (L2) learning studies employing computer-assisted language learning devices and applications to facilitate L2 learning process with a maximum level of flow (Bahari, 2020a). To compensate for the deficiencies of e-learning models and to integrate the element of over-simplification at learners' level, the model was used to address individual learner differences in terms of nonlinearity and dynamicity of learner differences to contrast against group learning complexity (Bahari, 2020b).

To contextualize the complexity of the individually-unique framework of learner style as reported by Larsen-Freeman and Cameron (2008), Bahari (2019a) introduced FonF practice model. As an individual-learner-friendly cooperative computer-assisted language learning practice model, it offered practices appropriate for the computer-assisted language learning environment. Elaborating on the from-structural perspective it represented the basic learning components of individual learner characteristics that vary from one learner to another to motivate learners to be engaged in learning materials/activities based on dynamic and nonlinear individual characteristics (Dörnyei \& Ottó, 1998) in an adaptable system. Reflecting Vygotskian notions of learning experience that moves from the individual to peer and back to the individual, the FonF practice model mirrors the dynamicity of intertwined learning experiences which are affected by internal and external factors/situations that are available at nonlinear and dynamic L2 learning conditions. Catering learner differences facilitates learners to masterL2 structures via creating automaticity, precision and familiarity with input components (Bahari, 202 la, 202 l b; Norris \& Ortega, 2000; Pawlak, 2006; Sheen, 2002). The aforementioned premise served as the rationale to use the FonF practice model by adapting it as the framework to conduct the current research to examine vocabulary learning in terms of incidental and intentional acquisition.

The FonF practice model was originally designed to address the nonlinearity and dynamicity of differences in learner and learning styles and preferences by Bahari (2019a) and integrating the suggestions provided by Larsen-Freeman and Cameron (2008) as an approach towards motivating learners and facilitatingL2learning process by integrating 
emerging educational technologies and reported affordances of computer-assisted language learning (Colpaert, 2018). The FonF practice model aims at integrating automatization of unequivocal data (DeKeyser, 1998) and the use of cognitive awareness by encouraging L2 learners' input awareness (Pawlak, 2006). The model comprises nine phases to work on listening-talking methodologies (see Figure I). The initial three phases of the model spotlight on grammar, the subsequent three phases center around meaning, and the third three phases center around communication.

To ensure the originality of the current study and to refine the findings reported by Bahari (2019a) who introduced and implemented the FonF model, a replication with extension research was conducted by including new variables in addition to the variable used in the original study (i.e. the nonlinearity and dynamicity of L2 motivation). To ensure the scientific rigor of the research outcomes and to avoid diverting the focus of the study from the original study, no changes were made to the stages of the FonF model that multidirectionally elaborated on listening and speaking skills through the FonF-situated techniques (Bahari, 2020c).

Therefore, while replicating a previously tested and contextualized pedagogical model, the present study aimed at staying away from secluded methodologies and unidirectional factor impact (de Bot, 2008) and single factor L2 learning exercises (Chang, 2005; Macaro et al., 2007) to enhance coordinating L2 learning exercises to ensure learning objectives. The administered stages required L2 learners to complete task reiteration with the least spans towards fostering collaboration between lexical conceptualization, suggesting scaffolding definitions, and exchange of explanations (Bygate \& Samuda, 2005). This string of educational interventions aimed at limiting/reducing the psychological burden by the use of affordances provided by FonF practice (Bahari, 2018) in the beginning phases of the treatment administration process and encouraging the association of language learning and individuallearner-oriented input. 


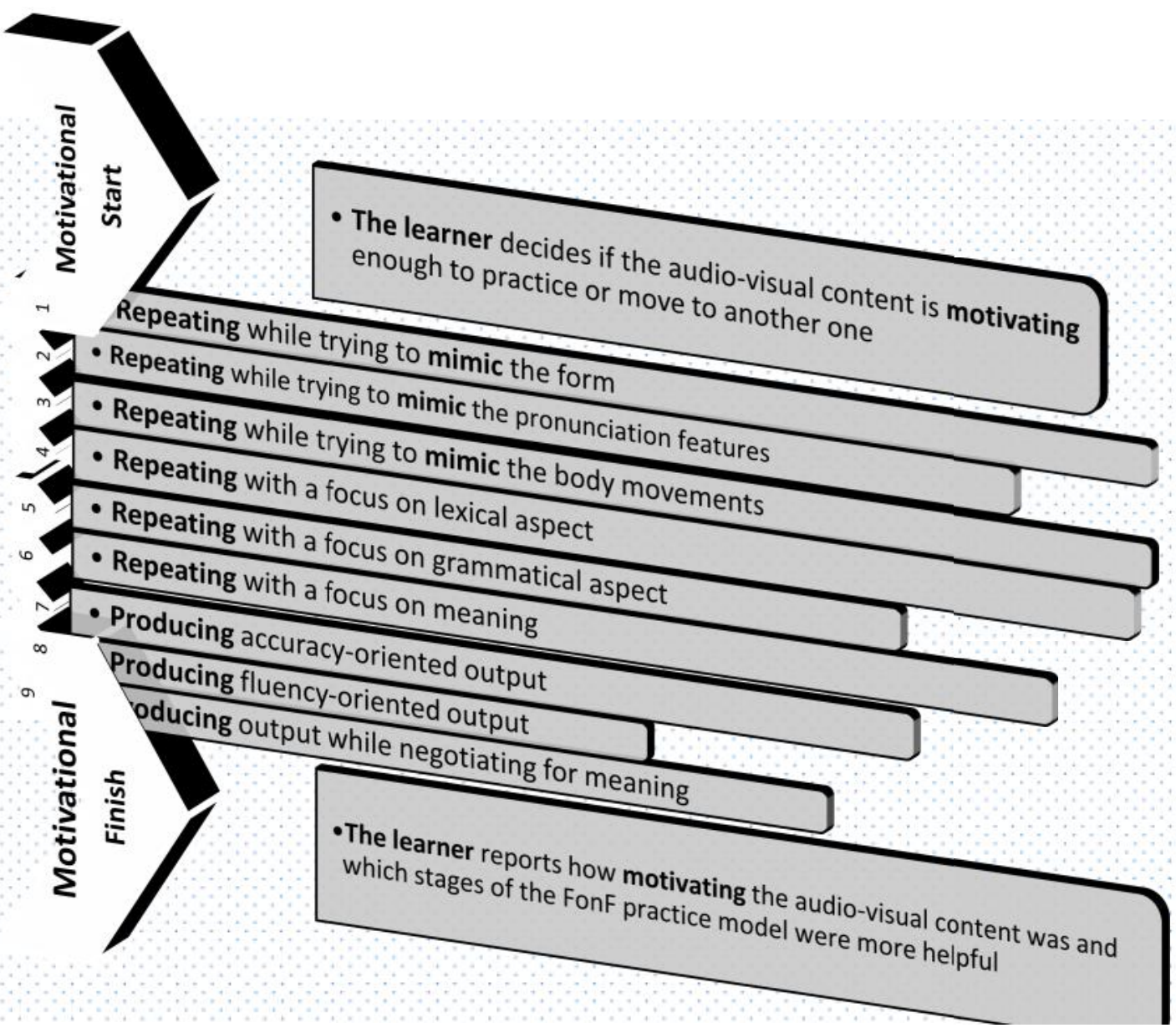

Figure I. The FonF Practice Model originally Developedby Bahari (2019a).

Mixed methods research was used among a group of 55 medical ESP students over a fourmonth course to test the efficacy of the model, The study observed all relevant ethical standards such as respect for anonymity, informed consent, and confidentiality while conducting the research. Participants with an average age of 20 were randomly assigned into two groups: the control group ( 9 female and 6 male) and the experimental group ( 28 female and 12 male). 
The FonF practice model-based educational intervention was administered among the members of the experimental group by the use of the computer-assisted language learning affordances in terms of podcasts, videos, quizzes, and games). No educational intervention was administered among the control group and they were instructed based on the officially designed syllabus by the instruction. To ensure interpretive rigor two expert scholars were invited to discuss the relevance and transferability of the inferences about the qualitative and quantitative data with respect to the research questions that follow:

- How efficacious is the FonF model in improving ESP learners' vocabulary learning in terms of intentional vocabulary acquisition in computer-assisted language learning environment?

- How efficacious is the FonF model in improving ESP learners' vocabulary learning in terms of incidental vocabulary acquisition in computer-assisted language learning environment?

- What is ESP learners' attitude toward the efficacy of three levels of the FonF practice model? 


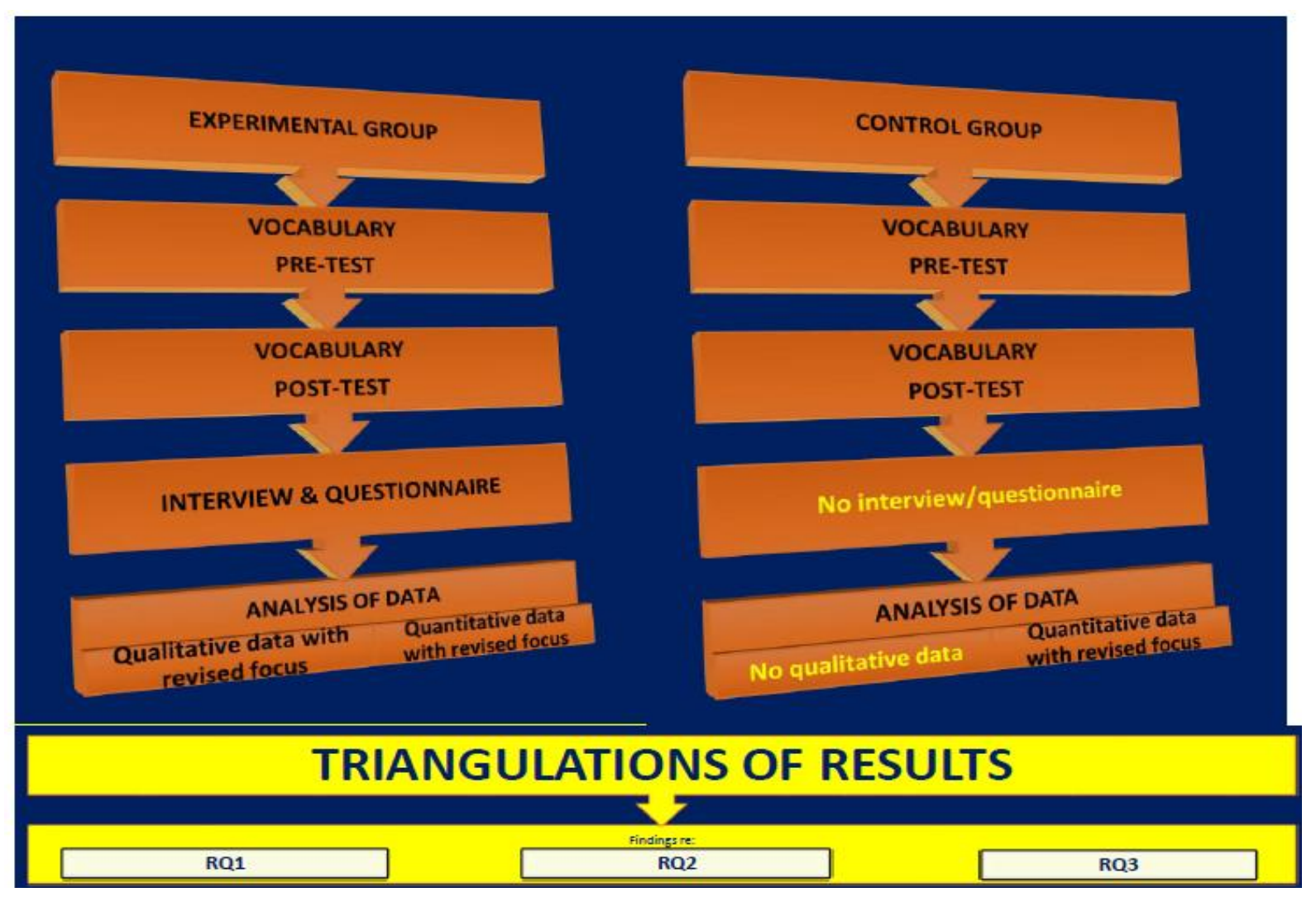

Figure 2. Visual Representation

Review of Related Literature

A survey of the computer-assisted language learning studies in the related literature uncovered a long list of tools and affordances (for example web-enhanced language learning, video games, and virtual reality) that reportedly facilitate L2 learning by introducing and emerging educational technology. Revealed viability of computer-assisted language learning affordances include the use of different games (Bahari, 2020a; Chiu, 2013), digital broadcasts (Winke et al., 20I3), and assessment (Arora et al., 20I5; Dumova, 20I2; Lu, 2009) reportedly facilitate various components of second language learning (e.g. receptive and productive skills, etc.) and have attracted several researchers. As per these investigations, computer-assisted language learning affordances can possibly advance commitment among the L2 students (Wilson et al., 20I3) and improve students' perspectives towards computerassisted language learning efficacy (Dashtestani, 20I5). Regardless of the presence of critical examinations explaining the adequacy of computer-assisted language learning tools and 
affordances, presenting and testing material practice models that can be received by educators and students to profit the most from computer-assisted language learning affordances is the primary challenge in writing proficiency. Such computer-assisted language learning -arranged practice models fill in as a guide for computer-assisted language learning practitioners and give an evaluated, efficacious, and efficient practice model.

The FonF drawing on learner-friendly approaches of L2 teaching (Long, 2000) aims at avoiding meaning-focused instruction and encouraging a "form-, meaning-, and communication-focused instruction” (Bahari, 2019a, p.4). The model engages L2 students in learning process by including a combination of planned and unplanned learning tasks (Ellis, 2016). This learner-friendly approach enhances L2 learners' flow and collaborative activity and enables teachers to handle errors via reactive, preemptive, and collaborative to enhance communicative accuracy. Based on the reported relationship between audiovisual materials and vocabulary learning (Vidal, 2003) and well as the effectiveness of exposure to meaningful input in facilitating L2 instruction (VanPatten, 2004), the FonF model was applied. To contextualize and examine its efficacy in developing incidental vocabulary (i.e. unplanned input of audiovisual content provided via computer-assisted language learning tools and affordances), and intentional vocabulary (i.e. planned input of audiovisual materials provided via computer-assisted language learning tools and affordances) a mixed methods research was conducted among the Iranian EFL learners.

\section{Method}

\section{Participants}

Mixed methods research approach was run to examine the efficacy of the model among 39 female and 23 male medical ESP participants who voluntarily consented to participate in the study. Some outliers $(n=7)$ were excluded from the study and the study was carried out with 55 Iranian EFL learners as the randomly sampled participants.

Four computer-assisted affordances available in online Merriam Webster dictionary (i.e. quiz, podcast, game, and video were employed as the medium to administer the educational 
intervention based on the stages outlined within the FonF practice model for the purpose of developing intentional and incidental vocabulary learning. Following the procedure, experimental participants were instructed to select and practice audiovisual instructional materials in order of proposed stages of the FonF practice model as displayed in Figure $\mathrm{I}$. To refrain from unwanted diversion of the study from the stated purpose of the research, the experimental participants were encouraged not to include learning activities and practices beyond the instructed ones at the beginning of the study. The experimental participants were engaged in educational treatment and guided throughout the study to ensure the consistency of the treatment (see Table I) and avoid including other unwanted factors that could negatively affect the research results.

Table I

Self-Report Form

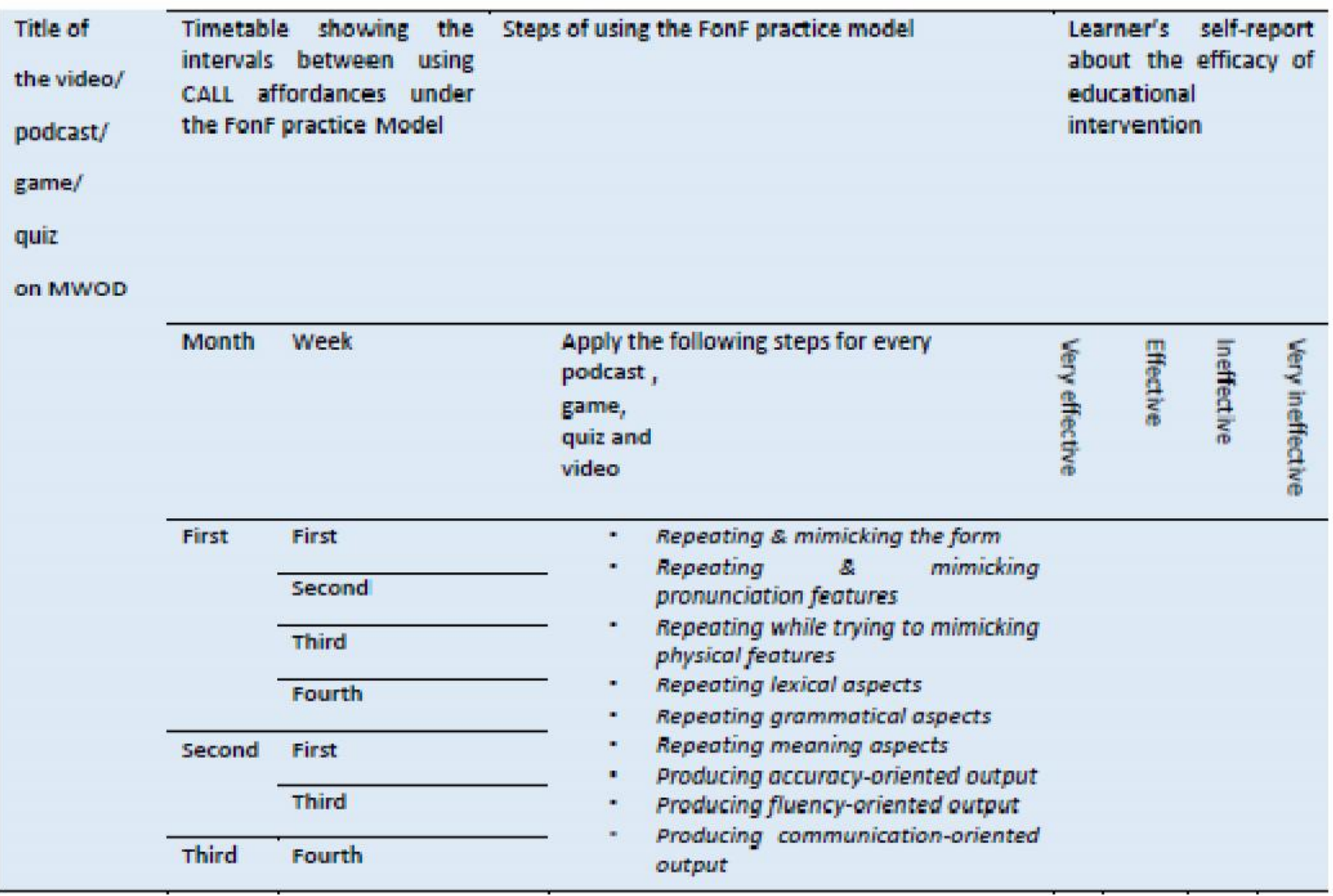




\section{Data Collection Procedure}

Given the complexity of lexical knowledge (Nassaji, 2004), we approached the vocabulary learning from a multidirectional approach from incidental and intentional learning perspectives. To this end, in keeping with Vidal (20II), participants were pretested before administering educational intervention and post tested following the treatment to measure possible differences (see Appendix A). The participants were asked to answer randomly selected items to evaluate the impact of administered educational intervention in terms of the intentional vocabulary acquisition; participants were instructed to practice and acquire 12 words. In keeping with Laufer (2006), participants memorized four nouns, four verbs, and four adjectives that were randomly selected along with their definition, example sentences, and Persian translation in a I5-minute span. Following Laufer's (2006) suggestions, translations of the items were provided and scored accordingly (see Appendix B). Both tests were used as the pretest and posttest on the participants to elicit the required data. The questionnaire eliciting participants' opinions concerning the efficacy of the FonF practice model (see Appendix C) a survey with sixteen items was developed by the authors to elicit participants' attitudes concerning intentional and incidental vocabulary. According to Wigfield \& Guthrie's alphas (1997) alphas, subscales (videos, podcasts, games, and quizzes showed reasonable reliability that ranged between .78 and $.8 \mathrm{I}$.

Table 2

Questionnaire Reliability

\begin{tabular}{lll}
\hline Subscale & N of Items & Reliability \\
\hline Individually-selected podcasts & 4 & .78 \\
Individually-selected videos & 4 & .78 \\
Individually-selected quizzes & 4 & .81 \\
Individually-selected games & 4 & .79 \\
\hline
\end{tabular}

Appendix $D$ is the adopted open-ended interview in the study that consists of four items designed to developed to collect the required data concerning the challenges and affordances in terms of Individually-selected quizzes, podcasts, videos, and games) to 
facilitate data analysis. Measuring reliabilities according to Wigfield and Guthrie's (1997) resulted in reasonable reliabilities that ranged between .70 and .80 (see Table 3).

Table 3

Interview Reliability

\begin{tabular}{lll}
\hline Subscales & N of Items & Reliability \\
\hline Podcast to develop incidental and/or intentional vocabulary & $\mathrm{I}$ & .74 \\
Video to develop incidental and/or intentional vocabulary & $\mathrm{I}$ & .70 \\
Quiz to develop incidental and/or intentional vocabulary & $\mathrm{I}$ & .72 \\
Game to develop incidental and/or intentional vocabulary & $\mathrm{I}$ & .80
\end{tabular}

Data Analysis

To analyze the collected data (i.e. quantitative and qualitative strands) in response to the research questions, first, the qualitative data were quantified by converting the elicited responses from the interviewees into scores and recording them into the SPSS dataset for descriptive statistics (e.g. frequency and percentile), second, the quantitative data obtained from the vocabulary pretest-posttest were analyzed by running t-test to find out the efficacy of the treatment and whether there is any statistically significant difference between the experimental and control group, third, both quantitative and qualitative data were triangulated to provide robust responses to the research questions.

\section{Results}

Table 4 shows the results of comparing control and experimental groups before and after the administering the educational intervention. Despite relative similarity between groups prior to the educational intervention in terms of Mean (experimental, $M=20.80$ and control, $M=2 I .45$ ) and Standard Deviation (experimental, $S D=2.6 I$ and control, $S D=I .18$ ) at pretest stage, we observe a significant difference at posttest stage (see Table 4). 
Table 4

Paired Samples Test

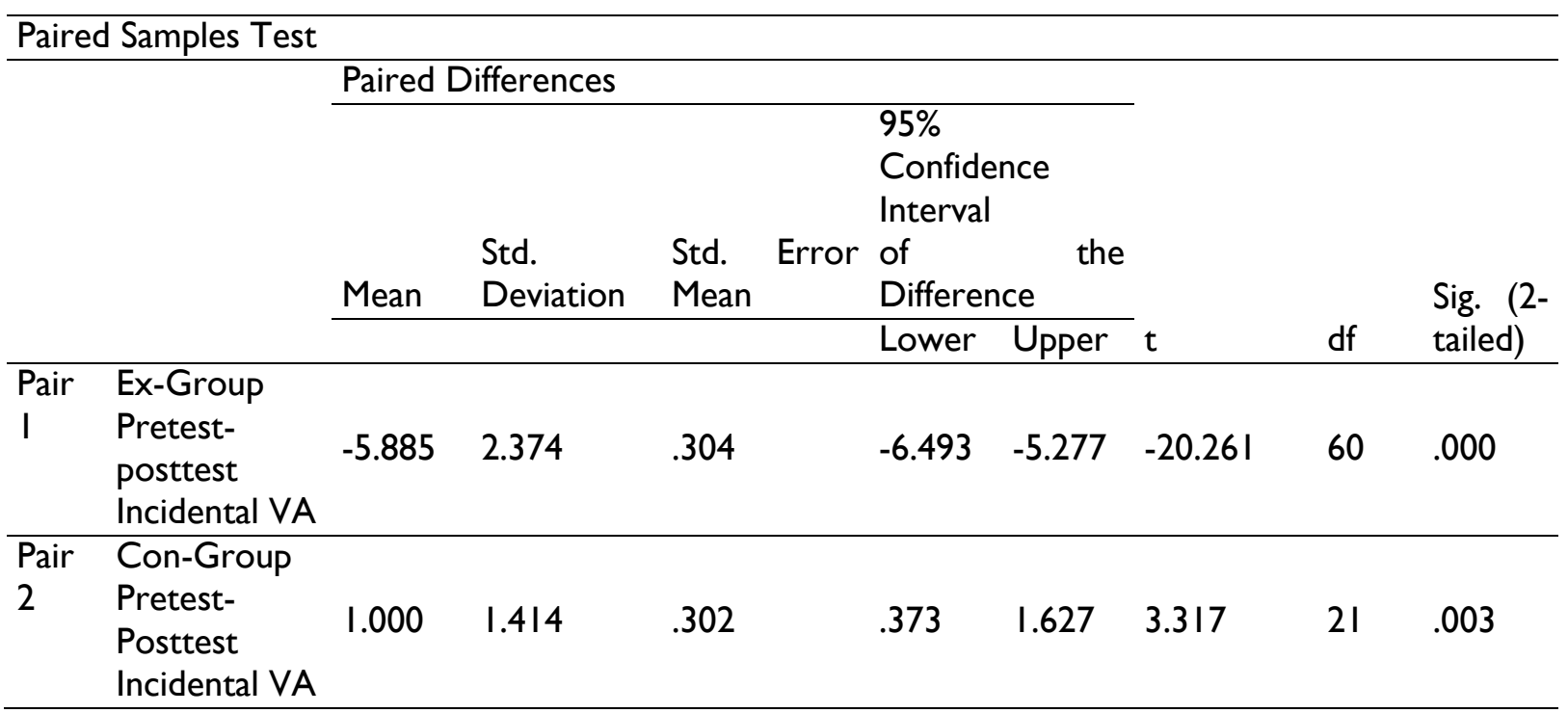

Table 5 shows that despite relative similarity of obtained scores at pretest (experimental group $M=23.05$ vs. the control group $M=23.5$ we observe a significant difference in the scores $(M=37.15)$ obtained by the experimental group following the administration of the treatment in terms of intentional vocabulary acquisition. 
Table 5

Paired Samples Test

Paired Samples Test

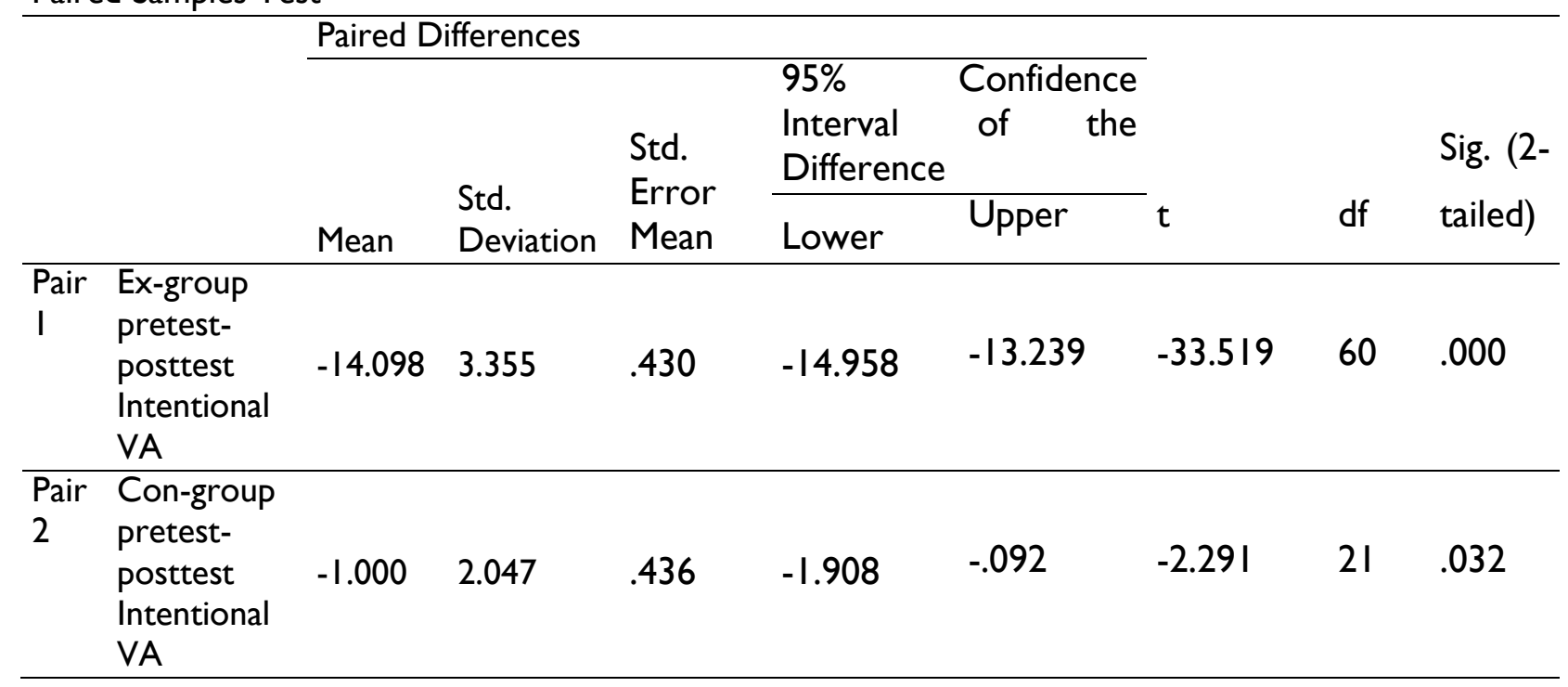

Table 6 displays statistically significant positive attitudes of the participants based on the elicited responses that support the efficacy of the administered treatment in the present study. According to the descriptive statistics, the majority of the respondents have positive attitudes towards the efficacy of the model and this serves as a sound evidence to support the consistency of the administered educational intervention and the objectives of the study in terms of developing vocabulary acquisition via computer-assisted tools and affordances. 
Table 6

Descriptive Results of the Administered Questionnaire

\section{Affordances}

Levels

\begin{tabular}{lllll} 
& Videos (\%) & Podcasts (\%) & Games (\%) & Quizzes (\%) \\
Strongly agree & 39 & 33 & 29 & 31 \\
Agree & 38.5 & 40 & 41 & 38 \\
Slightly agree & 15 & 21 & 23 & 21 \\
Slightly disagree & 3.5 & 2 & 3 & 6 \\
Disagree & 3.5 & 0.5 & 0.5 & 0.5 \\
Strongly disagree & 0.5 & 0.5 & 0.5 & 0.5 \\
\hline
\end{tabular}

\section{Discussion}

The triangulation of QUAN + QUAL data sources confirmed the effectiveness of the model in developing vocabulary acquisition as well as gender differences in vocabulary acquisition that is consistent with previous findings (Ivey, 1999; Shapiro \& Whitney, 1997). The triangulation of the elicited data from qualitative and quantitative methods supported the validity of the suggested strategies. Pedagogically, computer-assisted language learning practitioners are suggested to use the FonF practice model for the purpose of vocabulary building activities in terms of incidental and intentional acquisition. The findings also reflect the reported concern of computer-assisted language learning as depicted by Clifford and Granoien (2008) in terms of the informational construct of the learning process that might impact computer-assisted language learning teachers' attitudes towards the efficacy of these reportedly efficacious tools and devices in L2 vocabulary learning. The efficacy of the FonF practice model can serve L2 learners as a practice model and enhance vocabulary building practices in keeping with current and previous studies, including Tsou et al. (2006) to ensure creating a learner-friendly computer-assisted language learning environment (Bahari, 2020a).

\section{Conclusion}

According to the obtained results it can be concluded that practitioners of computerassisted language learning can use the FonF practice model as a technology-oriented 
pedagogical model to facilitate the second language (L2) learners' intentional and incidental vocabulary learning and accelerate the integration of the emerging educational technologies into L2 learning. The study was conducted among medical ESP learners, therefore, to replicate the present study, future studies are suggested to examine the efficacy of the model on other L2 learners studying other subjects to refine the findings of the present study and test its generalizability. The results of the study confirmed the efficacy of the FonF practice model in developing incidental and intentional vocabulary learning among ESP learners who used technology-based tools at form, meaning, and communication levels. Theoretically, the main implication of the study is the need to address individual differences in general and nonlinearity and dynamicity of L2 motivation in particular. Pedagogically, L2 teachers are suggested to benefit from reported computer-assisted tools and affordances to boost incidental and intentional vocabulary learning.

\section{References}

Arora, A., Evans, S., Gardner, C., Gulbrandsen, K, \& Riley, J. E.(20I5). Strategies for success: Using formative assessment to build skills and community in the blended classroom. In S. Koç,X. Liu, \& P. Wachira (Eds.), Assessment in online and blended learning environments (PP. 235-25I). Charlotte, NC: Information Age Publishing.

Bahari, A. (202la). Challenges and affordances of developing receptive and productive skills via technology-based instruction. Computer-Assisted Language Learning Electronic Journal (CALL-EJ), 22(I), 25-55.

Bahari, A. (202lb). Computer-assisted language proficiency assessment tools and strategies. Open Learning: The lournal of Open, Distance and e-Learning, 35(2), 3459.doi.org//0.1080/026805/3.2020.1726738

Bahari, A. (2020a). Game-based collaborative vocabulary learning in blended and distance L2 learning. The lournal of Open, Distance and e-Learning, 35(3), I22.doi.org//0.1080/026805/3.2020.18|4229.

Bahari, A. (2020b). CANDA: Computer-assisted nonlinear dynamic approach for the L2 teaching in blended and distance learning. Interactive Learning Environments, 28(6), II5.doi.org// 0.1080/I0494820.2020.1805774. 
Bahari, A. (2020c). Computer-mediated feedback for L2 learners: Challenges vs. affordances. Journal of Computer Assisted Learning, doi: I 0.I I I / jcal. I 248 I .

Bahari, A. (2019a). FonF practice model from theory to practice: CALL via focus on form approach and nonlinear dynamic motivation to develop listening and speaking proficiency. Computers \& Education, I30(3), 40-58. doi.org/10.1016/j.compedu.2018.1 1.009.

Bahari, A. (2019b). The impact of applying FonF practice model on developing L2 listening and speaking with a focus on intentional and incidental vocabulary acquisition in CALL context. Revistade Lingüística y Lenguas Aplicadas, 14, 4557.doi.org// 0.4995/rlyla.2019.10785

Bahari, A. (2018). Sacred text motivation for general 12 learners: a mixed methods study. Journal of Academic Ethics, I 6(4), I-3I. doi.org/ I 0. I007/s I 0805-0 I 8-93 I6-3

Bygate, M. \& Samuda, V. (2005). Integrative planning through the use of task repetition. In R. Ellis (Eds) Planning and task performance in a second language. Amsterdam/New York: Benjamins.

Chang, M. M. (2005). Applying self-regulated learning strategies in a web-based instruction: An investigation of motivation perception. Computer Assisted Language Learning, 18(3), 217-230.doi.org/10.1080/09588220500178939

Chiu, Y. H. (20/3). Computer-assisted second language vocabulary instruction: A metaanalysis. British Journal of Educational Technology, 44(2), E52-E56.

Clifford, R. \& Granoien, N. (2008). Application of technology to language acquisition processes: What can work and why. In M. V. Holland \& F. P. Fisher (Eds.), The path of speech technologies in computer assisted language learning: From research to practice (Pp. 2543). London, England: Routledge Language Learning.

Colpaert, J. (2018). Exploration of affordances of open data for language learning and teaching. Journal of Technology and Chinese Language Teaching, 9(I), I-I4.

Dashtestani, R. (20I5). Examining the use of web-based tests for testing academic vocabulary in EAP instruction. Teaching English with Technology, I5(I), 48-6I.

de Bot, K. (2008). Introduction: Second language development as a dynamic process. The Modern Language Journal, 92(2), I66-178.

DeKeyser, R. (1998). Beyond focus on form: Cognitive perspectives on learning and practicing second language grammar. In C. Doughty \& J. Williams (Eds.), Focus on form in classroom second language acquisition (pp. 42-63). Cambridge: CUP.

Dörnyei, Z. \&Ottó, I. (1998). Motivation in action: A process model of L2 motivation. Working Papers in Applied Linguistics (Thames Valley University, London), 4, 43-69. 
Dumova, T. (20/2). The usability of online quizzes: Evaluating student perceptions. In S. Kelsey, \& K. St. Amant (Eds.), Computer mediated communication: Issues and approaches in education (Pp. 50-6I). Hershey, PA: IGI Global.

Ellis, R. (2016). Focus on form: A critical review. Language Teaching Research 20 (3), 405428.

Fredricks, J. A., Blumenfeld, P. C., \& Paris, A. H. (2004). School engagement: Potential of the concept, state of the evidence. Review of Educational Research, 74(I), 59-109.

Ivey, G. (1999). A multicase study in the middle school: Complexities among young adolescent readers. Reading Research Quarterly, 34, 172-192.

Larsen-Freeman, D. \& Cameron, L. (2008). Research methodology on language development from a complex systems perspective. Modern Language Journal, 92, 200-13.

Laufer, B. (2006). Comparing focus on form and focus on forms in second-language vocabulary learning. The Canadian Modern Language Review, 63(I), I49-166.

Long, M. (2000). Focus on form in task-based language teaching. In Language Policy and Pedagogy, edited by R. H. Lambert and E. Shohamy, 179-192. Amsterdam: John Benjamins.

Lu, H. L. (2009). Pre-class online quizzing as a catalyst for pedagogical change. SOTL Commons Conference. Paper 56.

Macaro, E., Graham, S., \& Vanderplank, R. (2007). A review of listening strategies: Focus on sources of knowledge and on success. In A. D. Cohen \& E. Macaro (Eds.), Language learner strategies: 30 years of research and practice. Oxford: Oxford University Press, 165185.

Nassaji, H. (2004). The relationship between depth of vocabulary knowledge and L2 learners' lexical inferencing strategy use and success. The Canadian Modern Language Review, 6I, 107-134.

Nassaji, H. (20l6). Anniversary article: Interactional feedback in second language teaching and learning: A synthesis and analysis of current research. Language Teaching Research 20(4), 535-562.

Nassaji, H. \&Fotos, S. (20II). Teaching grammar in second language classrooms: Integrating form focuse dinstruction in communicative context. New York: Taylor \& Francis.

Norris, J., \& Ortega, L. (2000). Effectiveness of L2 instruction: A research synthesis and quantitative meta-analysis. Language Learning, 50, 417-528.

Pawlak, M. (2006). The place of form focused instruction in the foreign language classroom. Kalisz-Poznan': Wydawnictwo WPA UAM. 
Read, J. (2000). Assessing vocabulary. Cambridge University Press, Cambridge, UK.

Shapiro, J., \& Whitney, P. (1997). Factors involved in the leisure reading of upper elementary school students. Reading Psychology, I8, 343-370.

Sheen, R. (2002). Focus on form and focus on forms. ELT journal, 56(3), 303-305.

Tsou, W., Wang, W., \&Tzeng, Y. (2006). Applying a multimedia storytelling website in foreign language learning. Computers \& Education, 47(I), 17-28.doi.org/10.1016/j.compedu.

Vidal, K. (2003). Academic listening: A source of vocabulary acquisition? Applied Linguistics, 24(I), 56-86.

Vidal, K. (20II). A comparison of the effects of reading and listening on incidental vocabulary acquisition. Language Learning, 6I(I), 219-258. doi: 10.1III/j.I4679922.2010.00593.x

VanPatten, B. (2004). Input and output in establishing form-meaning connections. In B. VanPatten, J. Williams, \& S. Rott (Eds.), Form-meaning connections in secondlanguage acquisition (pp. 29-48). Mahwah, NJ: Erlbaum.

Vygotsky, L. S. (1997). The collected works of L. S. Vygotsky. Volume 4: The history of the development of higher mental functions (R. W. Rieber, Eds.). New York, NY: Plenum Press.

Wigfield, A., \& Guthrie, J.T. (1997). Relations of children's motivation for reading to the amount and breadth of their reading. Journal of Educational Psychology, 89(3), 420-432.

Wilson, A., Hainey, T. \& Connolly, T. M. (20I3). Using scratch with primary school children: an evaluation of games constructed to gauge understanding of programming concepts. International Journal of Games-Based Learning, 3(I), 25-4I.

Winke, P., Gass, S., \& Sydorenko, T. (20/3). Factors influencing the use of captions by foreign language learners: An eye-tracking study. The Modern Language Journal, 97(I), 254-75. 


\section{Appendix A}

Incidental Vocabulary Acquisition Scale Adapted from Vidal (20I I)

The subjects from both experimental and control groups were asked to respond to the following prompts:

I Have you heard/seen this word before? If so, where/when?

2 Provide a full explanation (in Persian or in English) of all the meanings of the word you know

3 Provide a Persian translation of the word

$4 \quad$ Make a sentence in English using the word

Scoring Scale

Point Knowledge of the word

-I recognizes a nonword

$0 \quad$ does not recognize the word

I recognizes having seen/heard the word

2 has a vague/partial idea of the meaning of the word

2.5 has a vague/partial idea of the meaning of the word but produces a clear example, similar to the one in the video/game/quiz/podcast

3 shows a full understanding of the meaning of the word

4 shows a full understanding of the meaning of the word and is able to provide a Persian translation or use the word in a sentence

5 shows a full understanding of the meaning of the word and is able to provide a translation and use the word in a sentence 


\section{Appendix B}

Intentional Vocabulary Acquisition Scale Adapted from Laufer (2006)

\begin{tabular}{|l|l|}
\hline LI-L2 & Test (Active knowledge test) \\
\hline Points & Knowledge of the word \\
\hline 2 & completely correct form \\
\hline I & $\begin{array}{l}\text { the correct word with a spelling error that did not interfere with the recognition of the } \\
\text { word }\end{array}$ \\
\hline 0 & a blank or an incorrect word \\
\hline L2-LI & Test \\
\hline Points & Knowledge of the word \\
\hline 2 & correct translation/explanation \\
\hline I & semantically approximate explanation/translation \\
\hline 0 & incorrect translation or a blank \\
\hline
\end{tabular}




\section{Appendix C}

Scales for statement-type items

\begin{tabular}{|c|c|c|c|c|c|c|c|}
\hline $\begin{array}{l}\text { Focus of } \\
\text { the } \\
\text { treatment }\end{array}$ & Statement & 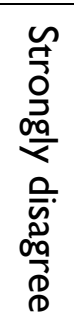 & 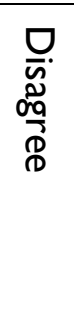 & 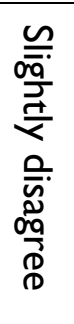 & 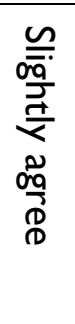 & $\underset{\substack{D \\
D}}{\stackrel{D}{D}}$ & 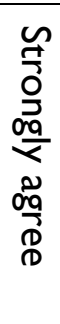 \\
\hline Podcast & $\begin{array}{l}\text { I consider using podcasts useful } \\
\text { to develop intentional } \\
\text { vocabulary. }\end{array}$ & & & & & & \\
\hline Podcast & $\begin{array}{l}\text { I consider using podcasts useful } \\
\text { to develop incidental vocabulary }\end{array}$ & & & & & & \\
\hline Quizzes & $\begin{array}{l}\text { I consider using quizzes useful to } \\
\text { develop intentional vocabulary }\end{array}$ & & & & & & \\
\hline Quizzes & $\begin{array}{l}\text { I consider using quizzes useful to } \\
\text { develop incidental vocabulary }\end{array}$ & & & & & & \\
\hline Videos & $\begin{array}{l}\text { I consider using videos useful to } \\
\text { develop intentional vocabulary }\end{array}$ & & & & & & \\
\hline Videos & $\begin{array}{l}\text { I consider using videos useful to } \\
\text { develop incidental vocabulary }\end{array}$ & & & & & & \\
\hline Games & $\begin{array}{l}\text { I consider using games useful to } \\
\text { develop intentional vocabulary }\end{array}$ & & & & & & \\
\hline Games & $\begin{array}{l}\text { I consider using games useful to } \\
\text { develop incidental vocabulary }\end{array}$ & & & & & & \\
\hline
\end{tabular}




\section{Appendix D}

\section{Interview}

I. How and why did games practiced under the FonF practice model, help you develop your incidental and/or intentional vocabulary acquisition?

2. How and why did quizzes practiced under the FonF practice model, help you develop your incidental and/or intentional vocabulary acquisition?

3. How and why did podcasts practiced under the FonF practice model, help you develop your incidental and/or intentional vocabulary acquisition?

4. How and why did videos practiced under the FonF practice model, help you develop your incidental and/or intentional vocabulary acquisition? 


\section{Appendix E}

Sample of Videos used as the CALL tools by the students from Merriam Webster to develop their incidental and intentional vocabulary
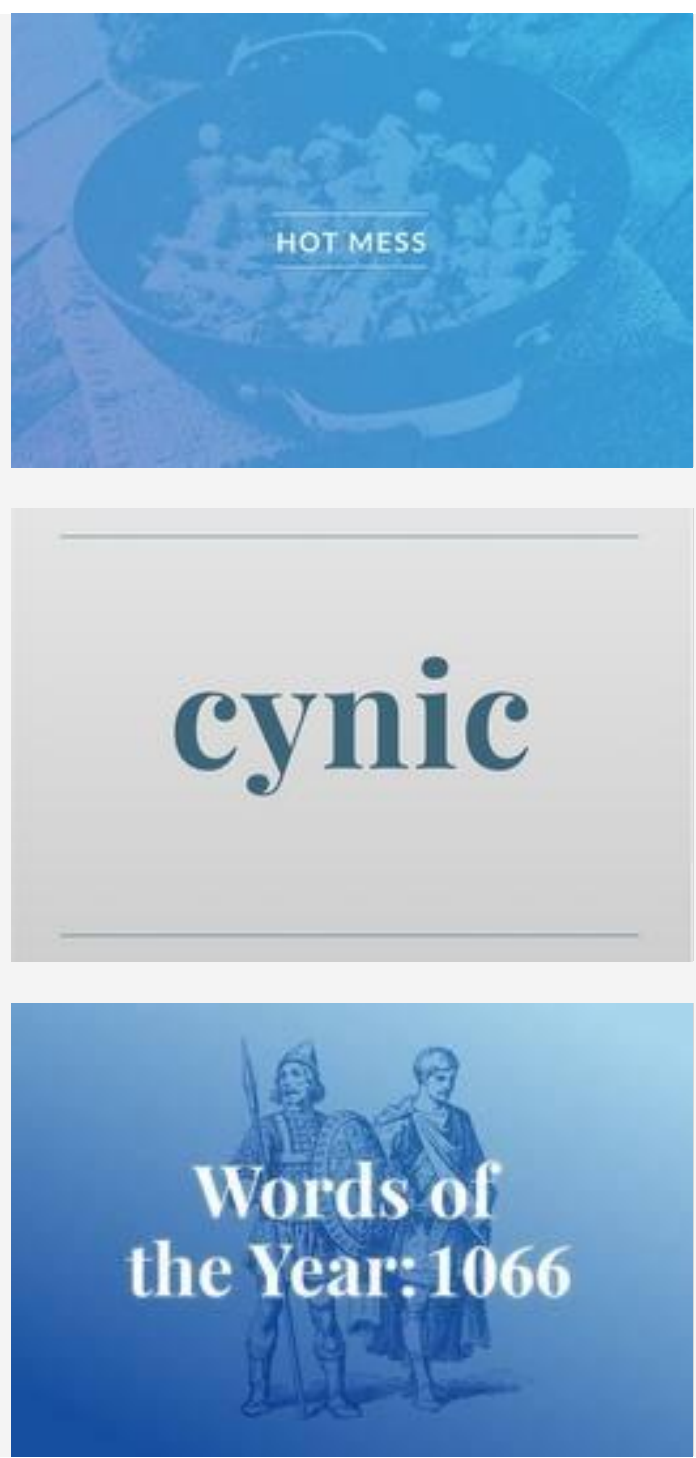